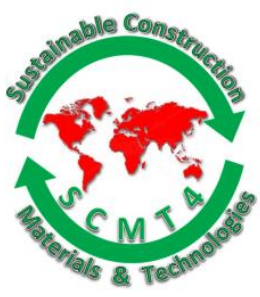

\title{
Restoration Approach to Improve Sustainability and Longevity in Existing Historical Structures
}

\author{
Baris Sayin*1a, Cemil Akcay ${ }^{1 b}$, Baris Yildizlarc, Turhan Bilir ${ }^{2}$ and T. Serhat Bozkurt ${ }^{3}$ \\ ${ }^{I}$ Department of Civil Engineering, Istanbul University, 34320, Turkey, ${ }^{1 a}$ Email: \\ <barsayin@istanbul.edu.tr>, ${ }^{1 b}$ Email: <cakcay@istanbul.edu.tr>, ${ }^{l c}$ Email: <peace@istanbul.edu.tr> \\ ${ }^{2}$ Department of Civil Engineering, Bulent Ecevit University, 67100, Turkey, \\ ${ }^{2}$ Email: 〈turhanbilir@karaelmas.edu.tr> \\ ${ }^{3}$ Department of Architecture, Istanbul Technical University, 34743, Turkey, \\ ${ }^{3}$ Email: 〈bozkurtt@itu.edu.tr>
}

\begin{abstract}
An aspect of the sustainable structure is the retrofitting of structural members in buildings and this yield to less use of natural resources and increase the strength of such materials for the same or similar purpose, thereby reducing waste as well. Sustainable structure also enhances the recycling of the industry as such materials are readily available in the world market. Structural materials are examples of sustainable materials and its combinations, however, the life time of structures and materials are decreased by environmental conditions, especially. Accordingly, repairing and strengthening of historical structures are an important factor in terms of transfer new generations and maintain preserving of such structures. This study focuses on restoration studies included repairing and strengthening, therefore, it is aimed to extend the buildings' service life and preserve its original structure and materials. In the present study, historical buildings, registered as protection required of cultural asset by the Protection of Cultural Assets District Board, is investigated. It is examined that retrofitting techniques in the buildings are performed repairing and strengthening applications by steel profile, jacketing, lime mortar, CFRP, steel mesh and injection according to material analysis on historical structural members.
\end{abstract}

\section{INTRODUCTION}

Sustainability is a vision of world aiming to meet economic, social and environmental needs without harming the living conditions of future generations. Another goal of the concept 'sustainable' is to allow future generations to be able to meet current needs. The concept 'sustainability' first, on the report published in World Commission on Environment and Development in 1987, was defined as meeting the current needs without compromising to be able to meet their own needs. It is known that, during the achievement of sustainable development, construction sector is one of the major factors affecting the environmental issues directly or indirectly, the constructions use a large amount of resources and produce waste and also the process of producing building component materials causes pollution and waste. 
Sustainable construction, literally, means the sustainable application of development policies to the surveillance of raw materials removing from nature by planning, designing and building of the constructions and infrastructure, dismantling of buildings and infrastructure, large-scale production cycle until the management of the waste occurs. As in developing countries, in Turkey, unhealthy urban agglomerations which cannot meet the sustainable needs are formed with fast and uncontrolled development.

The restoration of cultural heritage and the renovation of other historical buildings requires a whole and interdisciplinary approach, cooperation between experts and the use of modern computer-based instruments, appliances and tools with a single goal - sustainable renovation. The sustainable approach also requires a high professional level of activity and time to study and do research on the buildings [Akadiri 2015; Aydın and Alemdağ 2014; Çelebi and Aydın 2001; Galvez et al., 2013; Kang 2015; Perhavec et al., 2015; Piccinno et al., 2015].

In this study, it was presented that the surveillance of the practices carried out in the process of restoration of historical buildings in terms of sustainability and longevity. In this respect, it was emphasized that parameters of sustainability and longevity must be taken into consideration in the restoration study mentioned by presenting the positive effects of strengthening and repair applications carried out in different buildings of Istanbul University in details to increase the life of structures and materials.

\section{SUSTAINABILITY AND LONGEVITY IN HISTORICAL BUILDINGS}

Wood and steel usage as construction members. In historical buildings, making concrete slabs on the masonry walls which is the load-carrying member in the original case of the structure destroys the historical identity of the buildings, and also if concrete slabs completing the constructional life are removed, it is impossible to evaluate and give back to nature. Unlike the situation in concrete members, if steel building materials dismantled are melted, they can be re-produced and re-used. Concordantly, recycling of wooden slab is quite easy, if wood slabs completing the material life are dismantled, it can decompose quickly and does not harm the environment. Also, energy can be obtained from the wood slabs by burning.

Within the scope of matters mentioned, in historical buildings, concrete system selection incompatible with the original structure is not appropriate for the floorings to be positioned on the masonry walls. In the application held in a historical building restorated, concrete slabs completed its life cycle were dismantled and instead wood slabs were built by the help of steel fasteners (figure1).
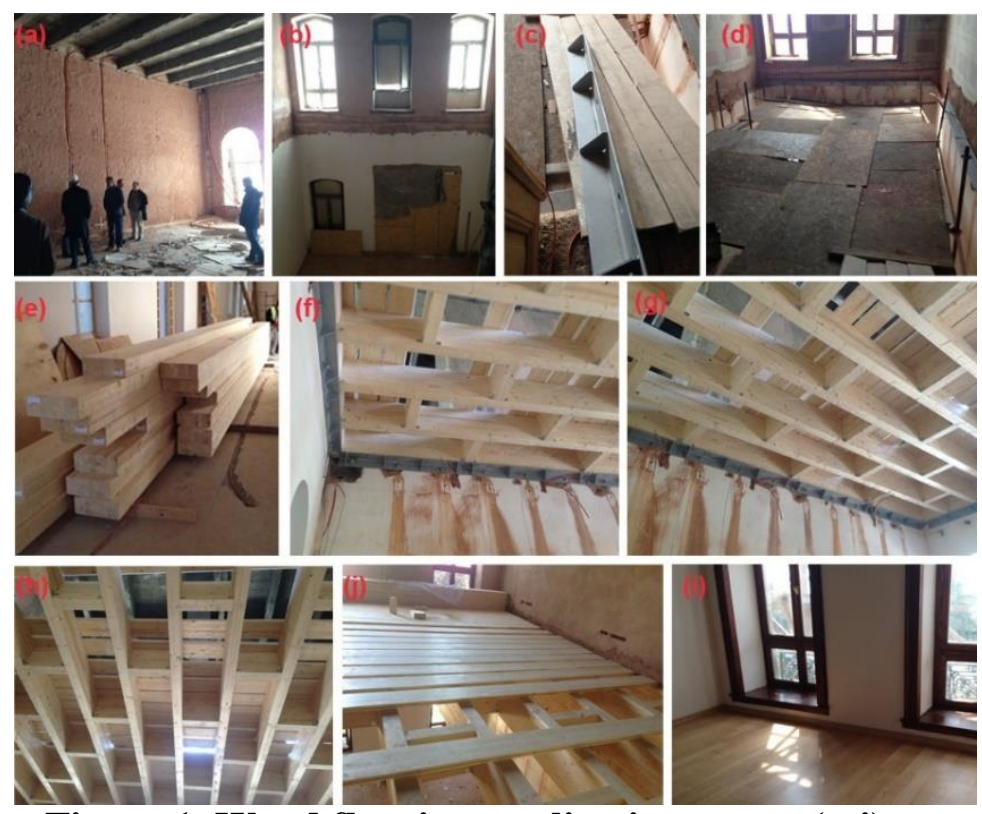

Figure 1. Wood flooring application stages (a-i) 
Increasing the structural life of the building and using the ground water. Istanbul University, Faculty of Science building was designed as a concrete bearing building in the 1950's, the basement of the 16th block was exposed to ground water for long years and structural deterioration occurred dramatically [Bozkurt et al, 2015]. For this reason, first, ground water was removed from the base by evacuating the ground water with the help of pump ( $i$ ) The production of steel bar links was completed by planting the ores on the foundation, (ii) Steel profile building up was carried out on shear walls, columns and slabs (iii) Completing of Steel bar arrangement on shear walls and columns, (iv) Concreting was performed with the help of self-compacting concrete in neighbourhood. Floor strengthening and structural life of the building registered as cultural assets and needs to be protected have been increased. These applications are shown in figure 2 .

Except for the 16th block building mentioned, well basis excavations and improvement applications with strengthening shear walls were held. In order to strength, well basis productions held in the central courtyard were carried out with timber support. Because dismantling of the timber support systems after the application is risky, it is estimated to decay in the natural process by leaving under the ground. In terms of decay time, because timber systems are shorter-timed than the steel and plastic systems, in similar types of well reinforcement applications, timber systems were preferred in terms of material recycling time. (Figure.3, a-f).

Refiling the floor by pumping the ground water out from the building and RC foundation prevented the possible negative effects. A part of the collected groundwater was used to water the garden and the irrigation of landscaping was provided. Similarly, in the pool system located in the garden, the amount of water to be used for landscaping was reduced by aiming at using ground water and recycling of groundwater was carried out. (figure.3, g-1).
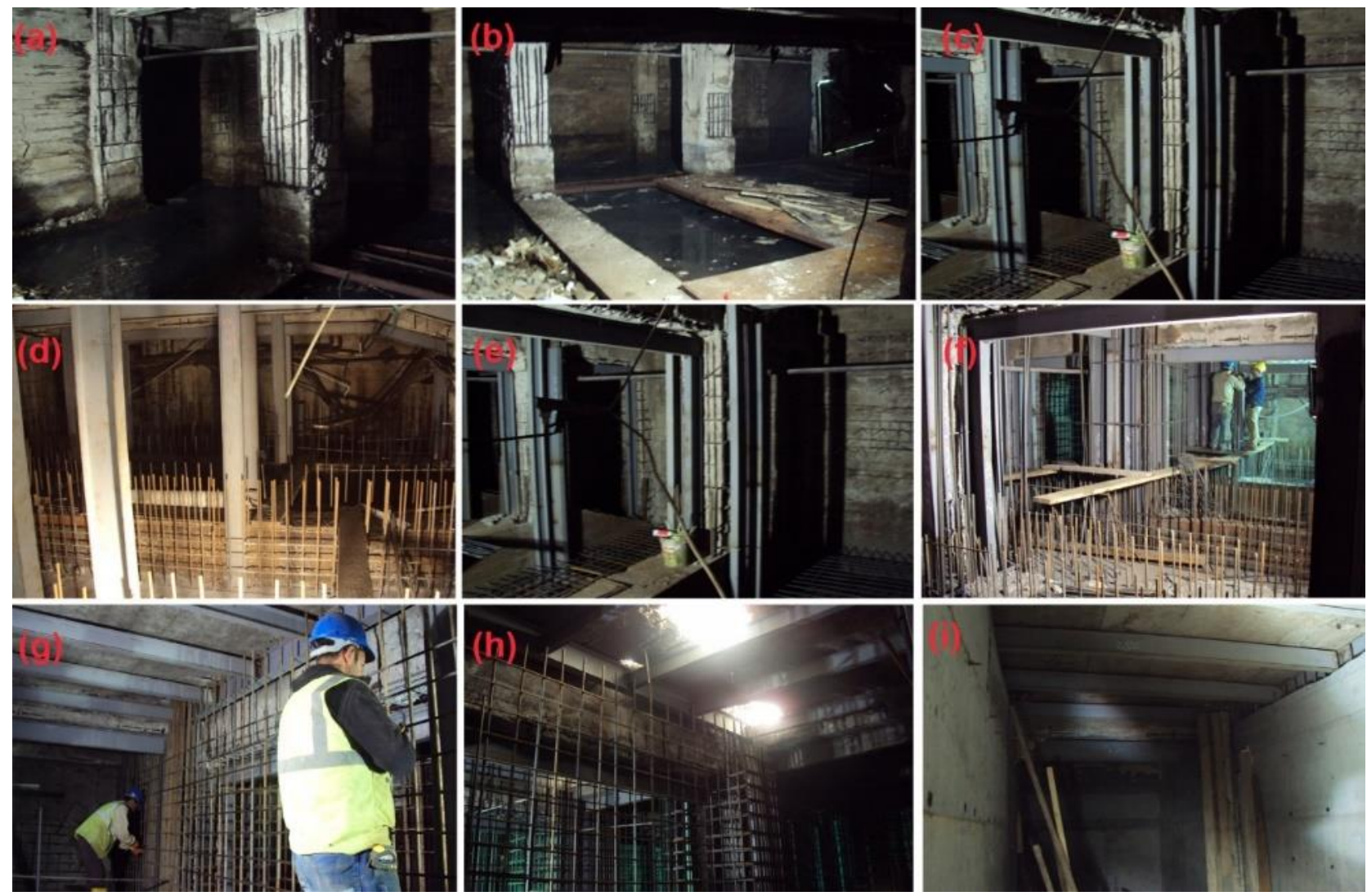

Figure 2. Basement strengthening steps, (a-i) 

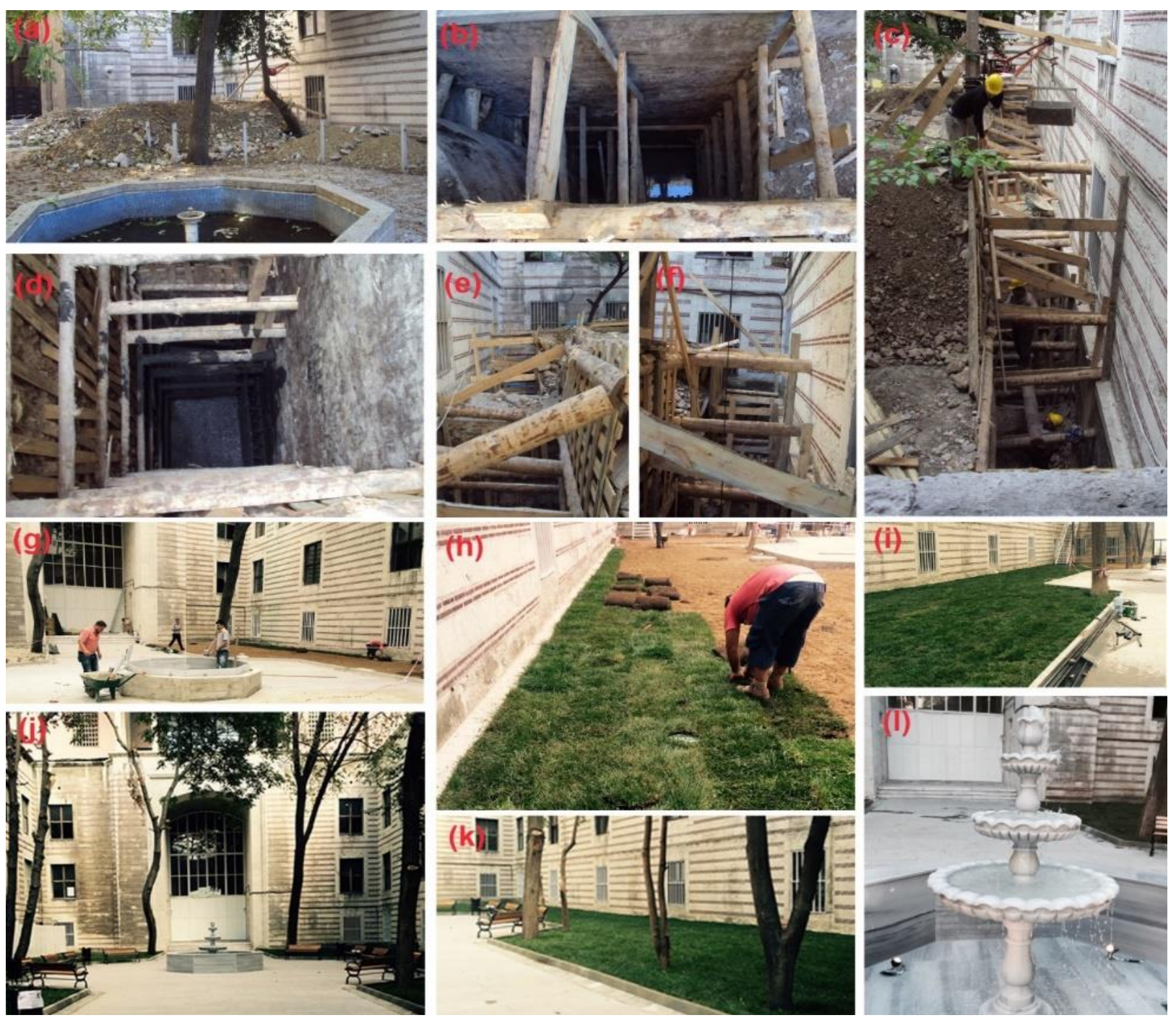

Figure 3. Well basis application and landscaping applications, (a-l)

Plaster applications in strengthening. In historical buildings, because it has a great importance to choose the appropriate materials according to the building, in masonry buildings made with lime binder, lime-based plaster needs to be used to be compatible with the original material. According to the mortar made with Portland cement, as lime-based mortar has a bigger pore rate, it contributes the building to breathe. In order to increase the performance of the reinforcement plaster, grout additive was added to hydraulic lime-based plaster mixture. In application stages, first, historical wall was scraped and a joint gaps were opened. Planting the ores was carried out on the historical wall with the help of epoxy and mesh building up has been completed on all the walls. In the last step, the work has been completed by applying the strengthening plaster applications on the wall surface in two stages. So, the economic life of the building was enhanced by a sustainability approach by choosing the strengthening system appropriate the original historical structure. Mentioned application stages were given in figure.4. 

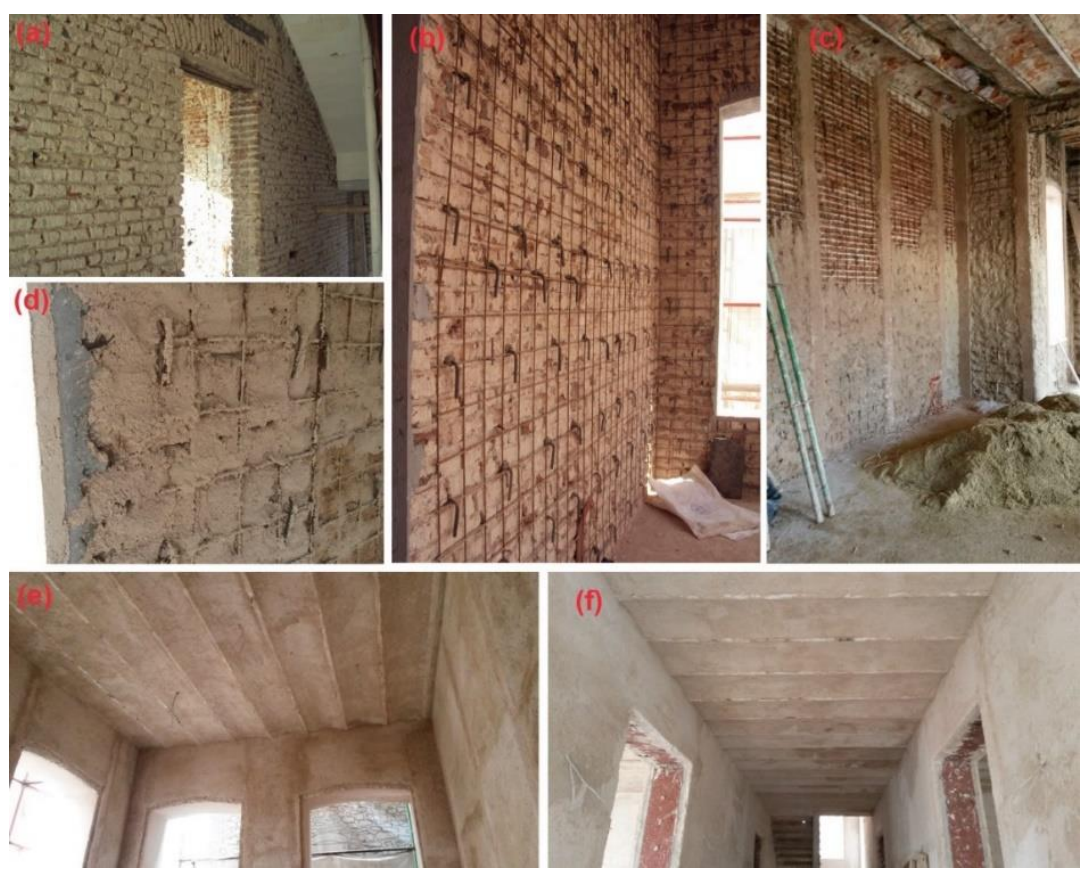

Figure 4. Strengthening plaster application stages, (a-f)

CFRP applications on strengthening. CFRP strengthening technique is used intensively restoration of historical buildings (Karakaş et al., 2015). Retrofit applications performed using CFRP materials to improve the static strength of the structure makes it preferable restoration of ancient monuments because; it can be performed at thin slice thickness, practicable without damaging the structure of spaces and forms. It is also important in terms of recycling that carbon wastes can be is converted into carbon reinforcing wraps. Recycling of waste materials and converting to increase the strength of the structural members in order to strengthen the application contribute nature conservation and the reduction of energy consumption. At figure 5, CFRP applications in the interior of a historical building can be seen.
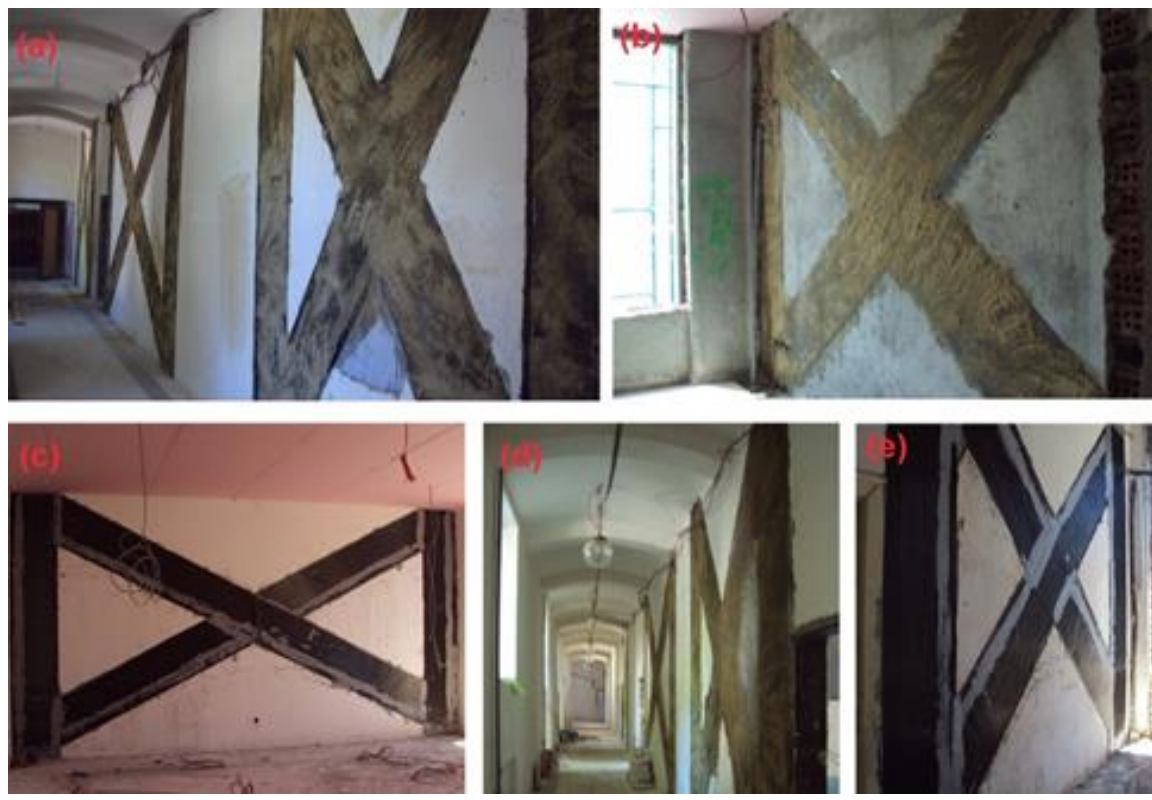

Figure 5. Retrofit applications made using CFRP wrap, (a-e) 


\section{CONCLUSION}

Building and construction industry play a key role in economic and social developments of countries. Within this scope; while use of modern materials - compared to the use of traditional ones given up- is getting widespread in building, restoration and reinforcement practises; the effects of these materials on environments and human beings are not to be ignored. Besides; sustainability principle should be evaluated as a considerable parameter in taking a decision as to the constructional or non-constructional materials chosen in the process of restoration as part of strengthening of buildings. The study focuses on the use of restoration applications as building components using sustainable materials. In the study; as part of several strengthening practises applied in administration and education buildings of Istanbul University and as part of sustainable construction techniques and materials selection as well; details of practises have been introduced aiming at prolonging the life of construction and materials. It is predicted that the study will guide the designers and builders in involvement decisions within the scope of restoration practises, supported with samples of sustainability concept.

\section{ACKNOWLEDGEMENTS}

The authors wish to thank Department of Construction and Technical Affairs, Istanbul University, for technical support.

\section{REFERENCES}

Akadiri P.O. (2015), "Understanding barriers affecting the selection of sustainable materials in building projects", Journal of Building Engineering, 4 (December 2015); 86-93.

Aydın, Ö and Alemdağ E.L (2014). "Sustainable materials in black sea vernacular architecture; wood and stone", The Journal of International Social Research, 7(35); 391-404.

Bozkurt T.S, Sayin B., Karakas A.S., Akcay C. and Yildizlar B. (2015). "The preserving and improvement of historical structures based on qualified a RC structure: A case study", CACMSISTANBUL 2015: International Conference on Advances in Composite Materials and Structures, 13-15 April, TR.

Çelebi, G.and Aydın, B. (2001). "Sürdürülebilir mimarlık yaklaşımında yapı malzemelerinin irdelenmesi”, IV. Ulusal Ekoloji ve Çevre Kongresi, 457-464.

Galvez, F.P., de Hita P.R., Martin M.O., Conde M.J.M. and Linan C.R. (2013), "Sustainable restoration of traditional building systems in the historical centre of Sevilla (Spain)", Energy and Buildings, 62(July 2013), 648-659

Kang H.J. (2015). "Development of a systematic model for an assessment tool for sustainable buildings based on a structural framework", Energy and Buildings, 104 (1), 287-301

Karakaş A.S., Bozkurt T.S., Sayın B., Akcay C. and Yıldızlar B. (2015). "Tarihi yapılarda restorasyon uygulamaları: Bir durum çalışması", ISITES 2015: 3rd International Symposium on Innovative Technologies in Engineering and Science, Universidad Politécnica de Valencia 3-5 June.

Perhavec D.D., Reboli D. and Suman N. (2015). "Systematic approach for sustainable conservation", Journal of Cultural Heritage, 16(1); 81-87.

Piccinno F., Hischier R., Saba A., Mitrano D., Seeger S. and Som C. (2015). "Multi-perspective application selection: a method to identify sustainable applications for new materials using the example of cellulose nanofiber reinforced composites", Journal of Cleaner Production, Available online 2 December 2015. 